\title{
Paleoparasitologic, paleogenetic and paleobotanic analysis of XVIII century coprolites from the church La Concepción in Santa Cruz de Tenerife, Canary Islands, Spain
}

\author{
Herminia Gijón Botella1, José A Afonso Vargas², Matilde Arnay de la Rosa², Daniela Leles ${ }^{3,4}$, \\ Emilio González Reimers ${ }^{5}$, Ana Carolina P Vicente ${ }^{3}$, Alena M Iñiguez ${ }^{3 /+}$ \\ 'Departamento de Parasitología, Facultad de Farmacia, Universidad de Granada, Granada, España \\ ${ }^{2}$ Departamento de Geografía y Historia, Universidad de La Laguna, La Laguna, Tenerife, España \\ ${ }^{3}$ Laboratório de Genética Molecular de Microorganismos, Instituto Oswaldo Cruz-Fiocruz, Av. Brasil 4365, 21045-900 - Rio de Janeiro, RJ, Brasil \\ ${ }^{4}$ Escola Nacional de Saúde Pública-Fiocruz, Rio de Janeiro, RJ, Brasil ${ }^{5}$ Hospital Universitário de Canárias, La Laguna, Tenerife, España
}

We present the results of a paleoparasitologic, paleogenetic and paleobotanic analysis of coprolites recovered during the excavation of the church La Concepción in Santa Cruz de Tenerife. Coprolites $(n=4)$ were rehydrated and a multidisciplinary analysis was conducted. The paleobotanic analysis showed numerous silicates, seeds and fruits of the family Moraceae. In the paleoparasitologic study, Ascaris sp. eggs $(n=344)$ were identified. The paleogenetic results confirmed the Ascaris sp. infection as well as the European origin of human remains. These findings contribute to our knowledge of ancient helminthes infections and are the first paleoparasitological record of Ascaris sp. infection in Spain.

Key words: paleoparasitology - Ascaris sp. - paleobotany - coprolite - paleogenetic - Canary Islands - ancient DNA

La Concepción was the major church of the ancient village of Santa Cruz de Tenerife in the centuries following the Spanish conquest. The church was not only the most important in the region, but also served as the community's cemetery. Following the Catholic liturgy, the dead were buried in the church foundation, a practice which began in the XVI century and persisted until the end of the XVIII century. The location of La Concepción near the seashore led to the relatively poor preservation of skeletal remains, but some archaeological studies have been possible (Gámez-Mendoza 2004, Arnay-de-la-Rosa et al. 2009). During the excavation, both bones and coprolites were recovered, which allowed us to conduct a multidisciplinary analysis.

Samples of coprolites $(n=4)$ were removed from tomb 146 (Fig. 1A), which contained a young female, whose sex was determined by cranial characteristics and whose age at death was determined by the absence of dental attrition (Ubelaker 1989). Coprolites were rehydrated by immersion in $0.5 \%$ aqueous trisodium phosphate for $72 \mathrm{~h}$, as described by Callen and Cameron (1960) (Fig. 1B). Seeds of fruits belonging to the family Moraceae were clearly visible in the coprolite. Microscopic investigation was performed using the methods described by Danielson and Reinhard (1998). This revealed numerous phytoliths derived from the silicated

Financial support: FAPERJ, IOC-FIOCRUZ

+ Corresponding author: alena@ioc.fiocruz.br

Received 10 June 2010

Accepted 21 September 2010 external envelopes of crop grains (silica skeletons) and starch grains corresponding to vegetables in the family Triticeae, which includes wheat and barley, indicating the presence of cereals in the diet. The paleoparasitologic investigation was conducted by microscopic analysis prior to the spontaneous sedimentation (Lutz 1919) of rehydrated coprolite solutions. We examined 20 slides for the presence of parasite eggs at magnifications of $100 \mathrm{X}$ and 400X. The results revealed the presence of Ascaris sp. eggs (Fig. 1C). The eggs measured 57.92-70.1 $\mu \mathrm{m}$ in length and 47.14-49.25 $\mu \mathrm{m}$ in width $(\mathrm{n}=344)$.

To ensure that authentic original sequences were analyzed by paleogenetic analysis, precautions to prevent contamination by modern DNA were followed as described by Drancourt and Raoult (2005). The preparation of sample, ancient DNA extraction and (aDNA) polymerase chain reaction (PCR) were performed at the Laboratory of Paleogenetics, Oswaldo Cruz Institute/ Oswaldo Cruz Foundation (IOC/FIOCRUZ). Electrophoresis, cloning, sequencing and sequence analysis were conducted at the Laboratory of Molecular Genetics of Microorganisms, IOC/FIOCRUZ. These two laboratories are physically distant from each other. The surface of the coprolites was removed, samples were irradiated with ultraviolet light and the aDNA was extracted as described by Iñiguez et al. $(2003,2006)$. The sediments of nine coprolites were submitted for molecular investigation. Human and Ascaris sp. targets were analyzed by procedures described by Fernandes et al. (2008) and Leles et al. (2008), respectively. For Ascaris sp. analysis, the primers of $18 \mathrm{~S}$ ribosomal DNA (rDNA) gene were used and others were designed based on the NADH dehydrogenase subunit 1 (nad1) and cytochrome c oxidase subunit 1 (coxl) genes (Table). PCR products were directly sequenced in both directions using a 3100 Automated DNA Sequenc- 

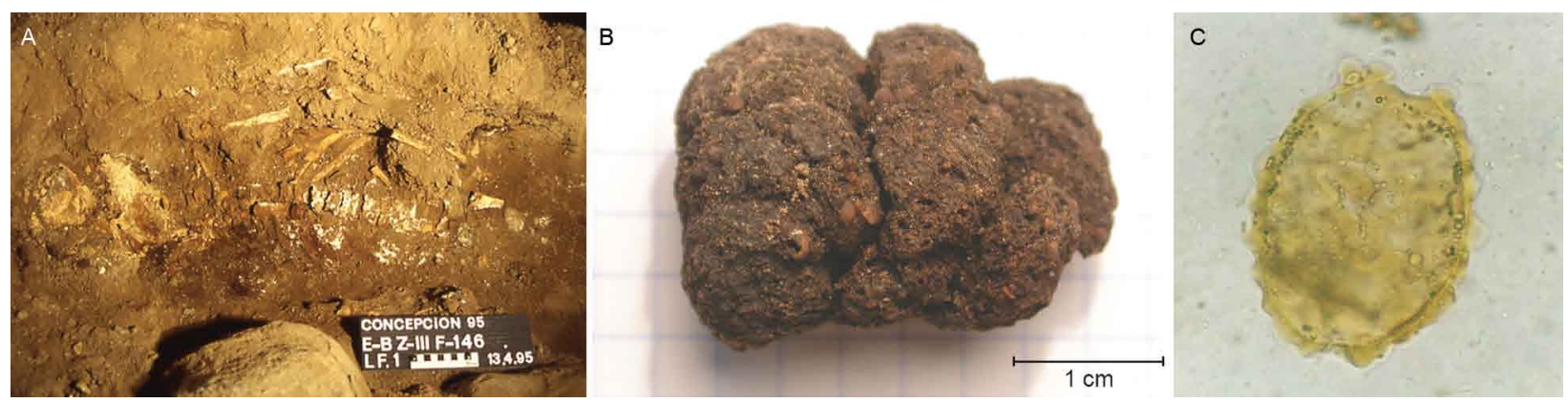

Fig. 1A: skeletal remains of a young female dated from XVIII century buried in La Concepción church, Canary Islands, Spain; B: coprolite sample from the human remains; C: Ascaris sp. egg $(66.10 \mu \mathrm{m} \times 47.96 \mu \mathrm{m})$ recovered after rehydration of the coprolite.

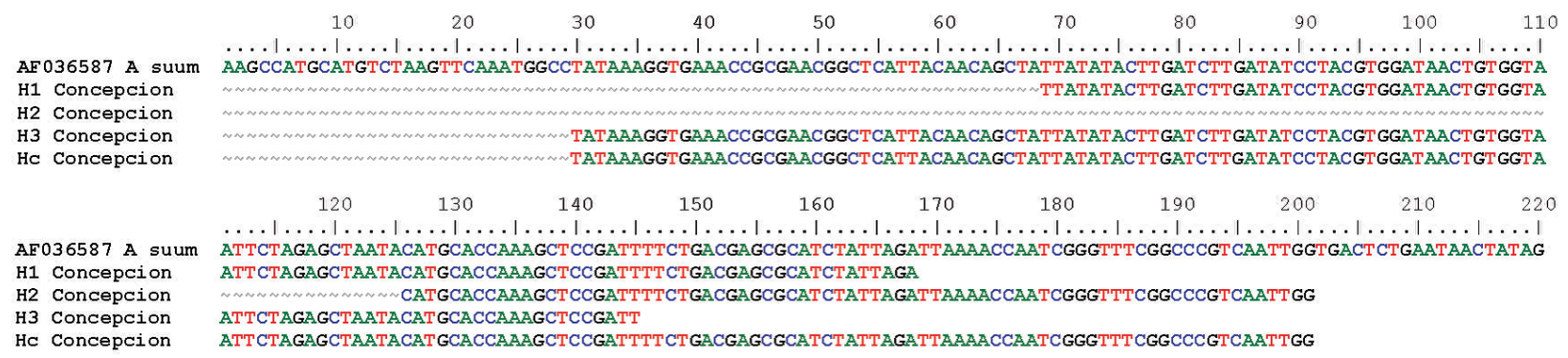

Fig. 2: alignment of Ascaris sp. 18S rDNA gene segments recovered from human coprolite material. H1-H3 corresponded to Ascaris sp. aDNA segments generated from combined primers. Hc corresponds to the consensus aDNA 18S rDNA sequence. Reference sequence AF036587 belongs to Ascaris suum.

TABLE

Primers used to amplify Ascaris sp. of ancient DNA samples

\begin{tabular}{|c|c|c|c|}
\hline Primer & Primer sequences & $\begin{array}{c}\text { PCR } \\
\text { product size }\end{array}$ & References \\
\hline \multicolumn{4}{|l|}{$18 \mathrm{~S}$ rDNA } \\
\hline Asc6 & 5'-CGAACGGCTCATTACAAC0AG-3' & \multirow[t]{2}{*}{$123 \mathrm{bp}$} & \multirow[t]{2}{*}{ Loreille et al. (2001) } \\
\hline Asc7 & 5'-TCTAATAGATGCGCTCGTC-3' & & \\
\hline Asc8 & 5'-ATACATGCACCAAAGCTCCG-3' & \multirow{2}{*}{99 bp } & \multirow{2}{*}{ Loreille et al. (2001) } \\
\hline Asc9 & 5'-GCTATAGTTATTCAGAGTCACC-3' & & \\
\hline Asc10 & 5'-CCATGCATGTCTAAGTTCAA-3' & \multirow{2}{*}{$147 \mathrm{bp}$} & \multirow{2}{*}{ Loreille et al. (2001) } \\
\hline Asc11 & 5'-CARAAAWTCGGAGCTTTGGT-3' & & \\
\hline \multicolumn{3}{|l|}{$\operatorname{cox} 1$} & \multirow{3}{*}{$\begin{array}{l}\text { Peng et al. (2005) } \\
\text { Designed in this study. }\end{array}$} \\
\hline As-Co1F & 5'-TTTTTTGGTCATCCTGAGGTTTAT-3' & \multirow[t]{2}{*}{199 bp } & \\
\hline COX1R & 5'-GCCCGAGAGTCAAGATCCAT-3' & & \\
\hline COX1F & 5'-GGATCTTGACTCTCGGGCTTA-3' & \multirow{2}{*}{248 bp } & \multirow{2}{*}{$\begin{array}{l}\text { Designed in this study. } \\
\text { Peng et al. (2005) }\end{array}$} \\
\hline As-Co1R & 5'-ACATAATGAAAATGACTAACAAC-3' & & \\
\hline \multicolumn{4}{|l|}{$\operatorname{nad} 1$} \\
\hline NAD1F & 5'-CTCCTCTGAATTCTTCGGAAA-3' & \multirow[t]{2}{*}{$152 \mathrm{bp}$} & \multirow[t]{2}{*}{ Designed in this study. } \\
\hline NAD1R & 5'-CAGAAAACCCAATCAAACACA-3' & & \\
\hline
\end{tabular}

PCR: polymerase chain reaction.

er (Applied Biosystems, Life Technologies, Foster City, CA, USA). The nucleotide sequences were analyzed with Lasergene ${ }^{\circ}$ SeqMan v.7.0.0 (DNASTAR, Madison, WI, USA) and Bioedit v.5.0.9 (Department of Microbiology, North Carolina State University, USA) softwares.
The human mitochondrial DNA (mtDNA) sequence was compared to mtDNA database from GenBank and from laboratory staff. We successfully recovered a segment of human mtDNA HVS-I region (16209-16356) and the European origin of the sample was confirmed based on 
signatures HVSI genetic (16224 and 16311) characteristic of haplogroup K. Ascaris sp. PCR products from $\mathrm{nad} 1$ and coxl were obtained, but the sequencing analysis revealed unspecific amplicons. However, the $18 \mathrm{~S}$ rDNA target was useful in yielding aDNA fragments corresponding to the Ascaris sp. gene in two different sediments. The assembly of aDNA fragments allowed the authentication of the $18 \mathrm{~S}$ rDNA amplicons (Fig. 2).

According to Gonçalves et al. (2003), Ascaris sp. eggs have been found in 39 European archaeological sites from 11 countries, excluding Spain. In this study we showed for the first time, by paleoparasitologic and paleogenetic analysis, that the occurrence of ascariasis in ancient times includes the Canary Islands, Spain. Despite the identification of human remains and human mtDNA haplotype recovery, we could not determine the species of Ascaris sp. parasite as Ascaris lumbricoides, the species of human origin, because the 18S rDNA gene does not discriminate to this taxonomic level. Nuclear and mitochondrial genes have been proposed to discriminate species of Ascaris, but the genetic definition between these closely related forms remains unclear (Anderson et al. 2001, Leles et al. 2010). The first molecular paleoparasitologic study of Ascaris sp. reported the recovery of aDNA from a concentrate of parasite eggs from the Middle Age site Place d'Armes in Namur (XIV century) (Loreille et al. 2001). Later, a sample from Walraversijde, Belgium (XVI century), which was used as positive control on South American paleogenetic analyses, showed a segment of cyt $b$ gene from aDNA directly extracted from coprolites (Leles et al. 2008). In this study, we confirm the ability of this methodology to recover aDNA without the prior concentration of parasite eggs (Iñiguez et al. 2003, 2006, Leles et al. 2008). This paleoanalysis, based on an interdisciplinary approach, is the first of its kind performed in archaeological samples from the Canary Islands.

\section{ACKNOWLEDGEMENTS}

To Koko Otsuki, from the Laboratory of Molecular Genetics of Microorganisms IOC-FIOCRUZ, Rio de Janeiro, for her excellent technical assistance, and PDTIS/FIOCRUZ genomic platform for nucleotide sequencing.

\section{REFERENCES}

Arnay-de-la-Rosa M, González-Reimers E, Gámez-Mendoza A, Galindo-Martin L 2009. The Ba/Sr ratio, carious lesions, and dental calculus among the population buried in the church La Concepción (Tenerife, Canary Islands). J Archaeol Sci 36: 351-358.

Anderson TJ 2001. The dangers of using single locus markers in parasite epidemiology: Ascaris as a case study. Trends Parasitol 17: 183-188.
Callen EO, Cameron TWM 1960. A prehistoric diet revealed in coprolites. New Sci 8: 35-40.

Danielson DR, Reinhard KJ 1998. Human dental microwear caused by calcium oxalate phytoliths in prehistoric diet of the lower Pecos region, Texas. Am J Phys Anthropol 107: 297-304.

Drancourt M, Raoult D 2005. Palaeomicrobiology: current issues and perspectives. Nat Rev Microbiol 3: 23-35.

Fernandes A, Iñiguez AM, Lima VS, Souza SM, Ferreira LF, Vicente AC, Jansen AM 2008. Pre-Columbian Chagas disease in Brazil: Trypanosoma cruzi I in the archaeological remains of a human in Peruaçu Valley, Minas Gerais, Brazil. Mem Inst Oswaldo Cruz 103: 514-516.

Gámez-Mendoza A 2004. Las investigaciones bioarqueológicas para ámbitos históricos en Canarias: la iglesia de Nuestra Señora de La Concepción de Santa Cruz de Tenerife como ejemplo. TABONA 13: 279-296.

Gonçalves ML, Araújo A, Ferreira LF 2003. Human intestinal parasites in the past: new findings and a review. Mem Inst Oswaldo Cruz 98 (Suppl. I): 103-118.

Iñiguez AM, Reinhard K, Carvalho Gonçalves ML, Ferreira LF, Araújo A, Paulo Vicente AC 2006. SL1 RNA gene recovery from Enterobius vermicularis ancient DNA in pre-Columbian human coprolites. Int J Parasitol 36: 1419-1425.

Iñiguez AM, Reinhard KJ, Araújo A, Ferreira LF, Vicente AC 2003. Enterobius vermicularis: ancient DNA from North and South American human coprolites. Mem Inst Oswaldo Cruz 98 (Suppl. I): 67-69.

Leles D, Araújo A, Ferreira LF, Vicente AC, Iñiguez AM 2008. Molecular paleoparasitological diagnosis of Ascaris sp. from coprolites: new scenery of ascariasis in pre-Columbian South America times. Mem Inst Oswaldo Cruz 103: 106-108.

Leles D, Araújo A, Vicente AC, Iñiguez AM 2010. ITS1 intra-individual variability of Ascaris isolates from Brazil. Parasitol Int 59: 93-96.

Loreille O, Roumat E, Verneau O, Bouchet F, Hänni C 2001. Ancient DNA from Ascaris: extraction amplification and sequences from eggs collected in coprolites. Int J Parasitol 31: 1101-1106.

Lutz A 1919. O Schistosomum mansoni e a schistosomatose segundo observações feitas no Brasil. Mem Inst Oswaldo Cruz 11: 121-155.

Peng W, Yuan K, Hu M, Zhou X, Gasser RB 2005. Mutation scanning-coupled analysis of haplotypic variability in mitochondrial DNA regions reveals low gene flow between human and porcine Ascaris in endemic regions of China. Electrophoresis 26: 4317-4326.

Ubelaker DH 1989. Human skeletal remains. In Manual on Archaeology 2, Smithsonian Institution, Washington, 172 pp. 